\title{
Morphology and Phylogeny of Two Novel Pleurostomatids (Ciliophora, Litostomatea), Establishing a New Genus
}

\author{
Hongbo Pan ${ }^{a, b}$ (D), Qianqian Zhang ${ }^{c}$, Jingyi Dong ${ }^{b}$ \& Jiamei Jiang ${ }^{a, d, e}$ (iD \\ a Shanghai Universities Key Laboratory of Marine Animal Taxonomy and Evolution, Shanghai Ocean University, Shanghai 201306, China \\ b Institute of Evolution and Marine Biodiversity, Ocean University of China, Qingdao 266003, China \\ c Key Laboratory of Coastal Environmental Processes and Ecological Remediation, Yantai Institute of Coastal Zone Research, \\ Chinese Academy of Science, Yantai 264003, China \\ d Shanghai Collaborative Innovation for Aquatic Animal Genetics and Breeding, Shanghai Ocean University, Shanghai 201306, China \\ e National Demonstration Center for Experimental Fisheries Science Education, Shanghai Ocean University, Shanghai 201306, China
}

\section{Keywords}

Apolitonotus gen. nov.; morphology; new species; Protolitonotidae; SSU rDNA.

\section{Correspondence \\ J. Jiang, College of Fisheries and Life Science, Shanghai Ocean University, Shanghai 201306, China \\ Telephone/FAX number: +86-21-61900427; e-mail: capitata@163.com}

Received: 9 September 2019; revised 24 November 2019; accepted November 27, 2019.

Early View publication December 30, 2019

doi:10.1111/jeu.12779

\begin{abstract}
Pleurostomatida Schewiakoff, 1896 is a cosmopolitan order of ciliates. In the present study, we investigated two new pleurostomatid species, Apolitonotus lynni gen. et sp. nov. and Protolitonotus clampi sp. nov., with state-of-the-art methods. Apolitonotus lynni lacks its oral extrusomes and its right kineties form an anterior semi-suture near the dorsal margin. Based on these two features, the new genus Apolitonotus was established within the Protolitonotidae Wu et al., 2017. Protolitonotus clampi differs from its congeners by its size of 80-130 × 15-30 $\mu \mathrm{m}, 4-6$ left, and 9-11 right kineties, extrusomes arranged along the oral slit, and two macronuclear nodules. Because Litonotus antarcticus possesses an anterior semi-suture and oral extrusomes, it was transferred to the genus Protolitonotus, becoming P. antarctius comb. nov. (basionym Litonotus antarcticus Song and Wilbert, 2002). Phylogenetic analyses based on SSU rDNA sequences suggest a sister group relationship of $P$. clampi and the family Kentrophyllidae, and A. lynni is adelphotaxon to Litonotus gracilis, both within the order Pleurostomatida. Based on the new findings, an improved diagnosis for Protolitonotus was also provided.
\end{abstract}

THE PLEUROSTOMATID ciliates are cosmopolitan organisms and one of the most common protozoan groups in the periphyton of aquatic environments. They act as predators of bacteria and other protozoa in biofilms (Dopheide et al. 2009). Together with other periphytic ciliates, such as hypotrichs, euplotids, and dysterids, pleurostomatids are good indicators for monitoring water quality (Xu et al. 2014) and may influence invertebrate settlement (Shimeta et al. 2012).

In contrast to other orders in the subclass Haptoria Corliss, 1974, the Pleurostomatida can clearly be identified by their distinctly laterally flattened body shape, the slit-like cytostome, and somatic kineties on the left body side composed of bristle-like cilia (Lynn 2008). To date, more than 100 nominal pleurostomatid species have been described (Vd'ačný et al. 2015). However, most of them have only been described based on live observations, and not after application of state-of-the-art methods (Warren et al. 2017), which causes considerable taxonomic confusion/uncertainties. Recent taxonomic studies (Foissner et al. 1995; Lin et al. 2009; Liu et al. 2017; Pan et al. 2010, 2013; Wu et al. 2013, 2015b) could partly resolve the confusions and described dozens of new organisms. However, the diversity of pleurostomatids is still underestimated.

The monophyly of the order Pleurostomatida is supported by both single gene- (SSU rDNA) and multiple gene-based (LSU rDNA, ITS1-5.8s-ITS2 and alpha-tubulin genes) phylogenetic analyses (Gao et al. 2008; Huang et al. 2018; Pan et al. 2014, 2015; Vd'ačný et al. 2015; Wu et al. 2014, 2015a,b, 2017; Zhang et al. 2012). For a long time, Pleurostomatida comprised only two families, the Amphileptidae and Litonotidae, which differ in terms of the presence/absence of an anterior suture formed by ciliary rows on the right side (Lynn 2008). Owing to the increasing number of described species, the phylogeny of 
Pleurostomatida was drastically revised, and two families, the Kentrophyllidae and Protolitonotidae, have been established (Wu et al. 2015b, 2017). In kentrophyllids, the right ciliary rows form both an anterior suture and a posterior suture, whereas in protolitonotids the right ciliary rows are progressively shortened along rightmost kineties in the anterior portion and form an incomplete suture, viz., semisuture. The updated molecular phylogenetic trees indicated that the Protolitonotidae was the basal pleurostomatid group (Wu et al. 2017). However, the most common pleurostomatid genera, Amphileptus and Litonotus, have been regarded as nonmonophyletic groups (Pan et al. 2015; Vd'ačný et al. 2015; Wu et al. 2015b).

Recently, a series of investigations on the diversity of ciliated protozoa has been carried out along Chinese coasts, especially in mangrove, wetland, and estuary habitats. Fifty-five pleurostomatid species have been discovered, three quarters of which are new. (Hu et al. 2019; Liu et al. 2017; Song et al. 2009). As a new contribution, we isolated two distinct pleurostomatid organisms, one from a mangrove habitat in South China and the other from coastal waters of the Yellow Sea. After detailed morphological studies, we could not assign them to any nominal species. Furthermore, one species likely represents a new genus belonging to Protolitonotidae. The SSU rDNA of both species were obtained and investigated. Interestingly, the molecular findings contradict the morphological similarity, which challenges our understanding about the known diversity and the phylogeny of Protolitonotidae.

\section{MATERIALS AND METHODS}

\section{Sample collection, observation, and identification}

Apolitonotus lynni gen. et sp. nov. was collected with water and surface sediments during the ebb tide on April 7, 2010, from a mangrove wetland on Techeng Island $\left(21^{\circ} 08^{\prime} 52^{\prime \prime} \mathrm{N}, 110^{\circ} 26^{\prime} 20^{\prime \prime} \mathrm{E}\right)$, Zhanjiang, Guangdong Province, China, with a water temperature of $24^{\circ} \mathrm{C}$, a salinity of $26.3 \%$, and a $\mathrm{pH}$ of 8.2 .

Protolitonotus clampi sp. nov. was isolated on October 29, 2009, from the coastal water of the Qingdao Olympic Sailing Centre $\left(36^{\circ} 03^{\prime} 26.7^{\prime \prime} \mathrm{N}, 120^{\circ} 23^{\prime} 42.8^{\prime \prime} \mathrm{E}\right)$ in Qingdao, China, using the slide method. The water temperature was $18{ }^{\circ} \mathrm{C}$, and the salinity was $31 \%$. For detailed sampling method, see Cairns and Yongue (1968). Generally, samples were collected with framed slides, which were immersed in the water at the depth of $0.5 \mathrm{~m}$ for 10 days.
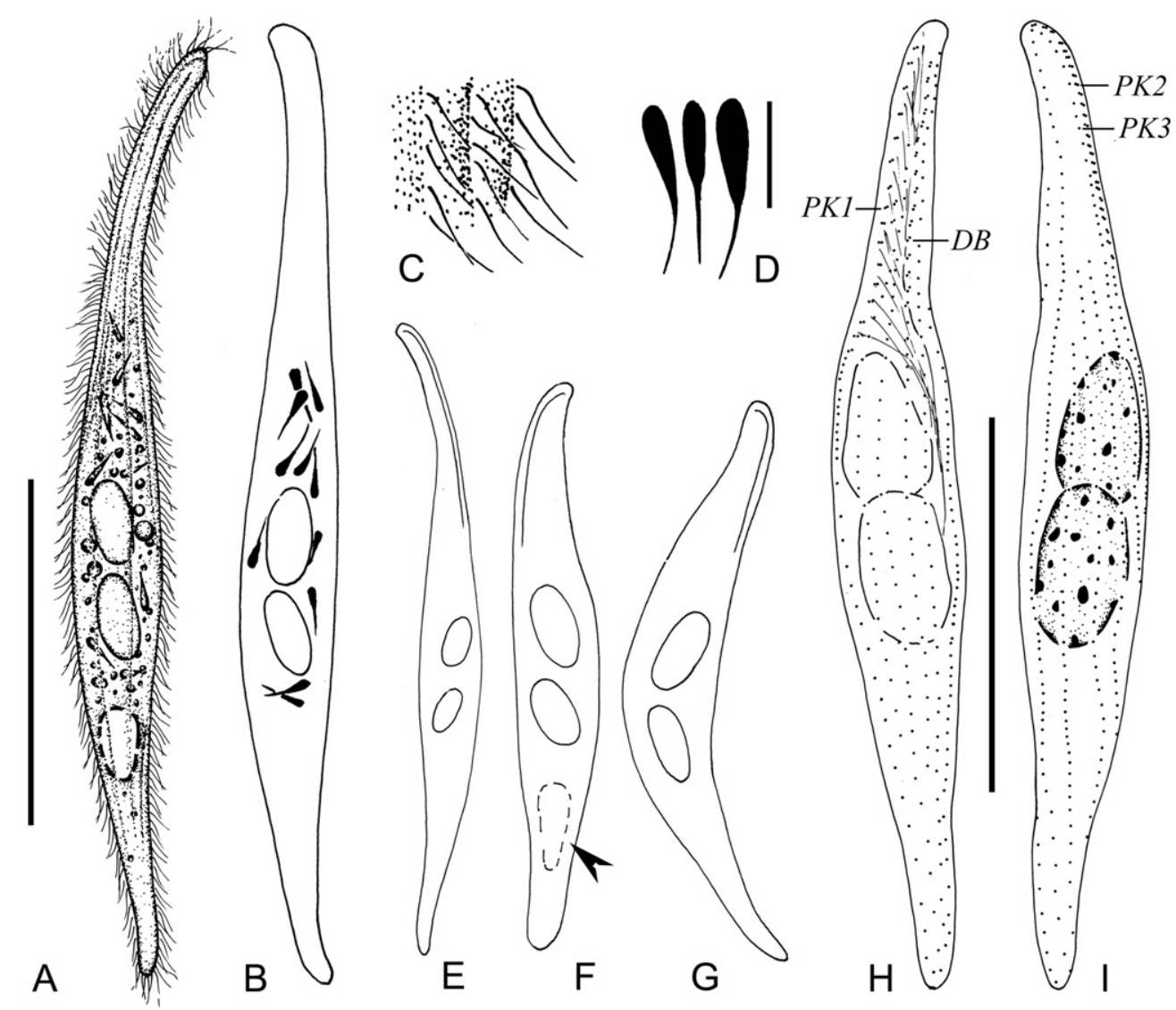

Figure 1 Apolitonotus lynni gen. et sp. nov. from life (A, C, D, E-G) and after protargol staining (B, H, I). (A) Left view of a typical individual. (B) To show the distribution of extrusomes. (C) Cortical granules between kineties. (D) Extrusomes. (E-G) Shape variants, arrowhead indicates the contractile vacuole. $(H, I)$ Left $(H)$ and right (I) views. DB = dorsal brush; PK1-3 = perioral kineties 1-3. Scale bars: $50 \mu \mathrm{m}(\mathrm{A}, \mathrm{H}, \mathrm{I}), 6 \mu \mathrm{m}(\mathrm{D})$. 


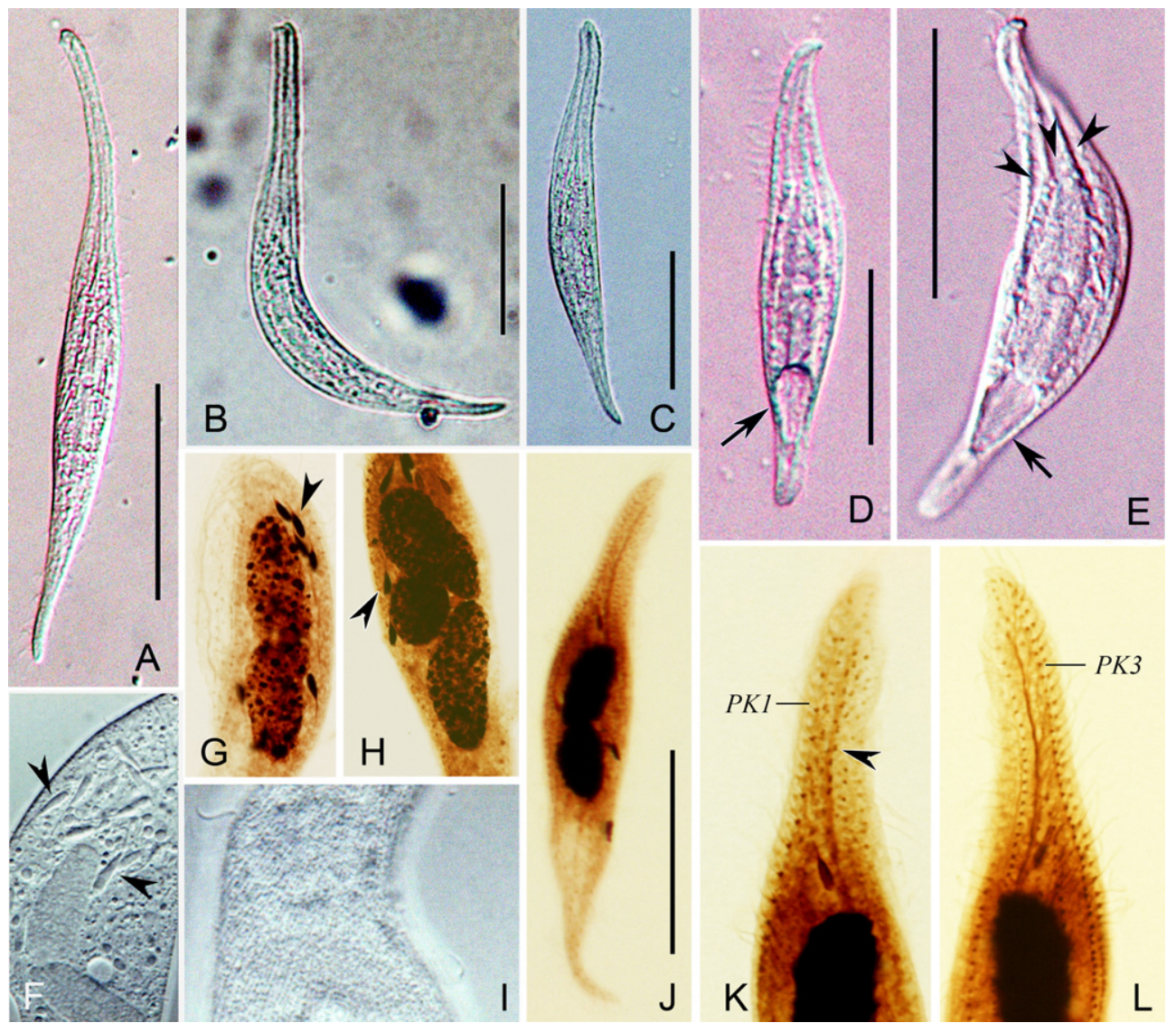

Figure 2 Apolitonotus lynni gen. et sp. nov. from life (A-F, I) and after protargol staining (G, H, J-L). (A) Left view of a typical individual. (B-E) Shape variants, arrows mark the contractile vacuoles, arrowheads point to furrows. (F) Extrusomes (arrowheads). (G, H) To show the macronuclear nodules and the extrusomes (arrowheads). (I) Cortical granules. (J) Left view. (K, L) Left (K) and right (L) views of anterior cell portions, arrowhead points to the dorsal brush. PK1, 3 = perioral kinety 1, 3. Scale bars: $50 \mu \mathrm{m}$.

After collection, the samples were transported to the laboratory, and morphological investigations were conducted immediately. Live cells were studied using brightfield and differential interference contrast microscopy (E600; Nikon, Tokyo, Japan). Ciliary patterns were revealed with the protargol staining method (Wilbert 1975). Counts and measurements on stained specimens were performed at a magnification of 1,000X. Illustrations of stained specimens were drawn, using a camera lucida. Terminology and systematics mainly base on Gao et al. (2016), Lynn (2008), and Wu et al. (2017).

\section{DNA extraction, amplification, and sequencing}

Prior to DNA extraction, one cell of A. Iynni and four cells of $P$. clampi were isolated from the raw samples with autoclaved micropipettes and washed five times with sterile habitat water. DNA extraction, PCR amplification of the small subunit rDNA (SSU rDNA), and sequencing were performed as described in Chen et al. (2018) and Wang et al. (2019). The EukA and EukB primers (Medlin et al. 1988) were used for PCR amplification.

\section{Phylogenetic analysis}

To determine the phylogenetic positions of A. lynni gen. et sp. nov. and P. clampi sp. nov. within the order Pleurostomatida, the new SSU rDNA sequences were aligned with those of 33 other pleurostomatids, one undetermined ciliate and five haptorids obtained from the GenBank database, using the program MUSCLE 3.8.31 (Edgar 2004). Five haptorids (Enchelyodon sp. U80313, Fuscheria sp. JF263448, Didinium nasutum U57771, Monodinium sp. DQ487196, and Homalozoon vermiculare L26447) were chosen as the outgroup taxa according to Huang et al. (2018). Ambiguously aligned regions were masked, using Gblocks v0.91b with the option to allow smaller final blocks (Castresana 2000). The final alignment consisted of 41 taxa and 1,656 nucleotide characters. Maximum-likelihood (ML) analysis was carried out with 1,000 replicates, using RAxML-HPC2 v8.2.10 (Stamatakis 2014) on XSEDE on the CIPRES Portal (Miller et al. 2010). Bayesian inference (BI) analysis was performed, using MrBayes v3.2.6 on the CIPRES Portal (Ronquist and Huelsenbeck 2003) with the $\mathrm{G}+\mathrm{I}+\Gamma$ substitution model as suggested by 
Table 1. Morphometric characteristics of Apolitonotus lynni gen. et sp. nov. (upper line) and Protolitonotus clampi sp. nov. (lower line) from protargol-stained specimens

\begin{tabular}{|c|c|c|c|c|c|c|}
\hline Characters & Min & Max & Mean & SD & CV & $n$ \\
\hline \multirow[t]{2}{*}{ Body, length } & 83 & 146 & 111.8 & 20.30 & 18.2 & 20 \\
\hline & 68 & 130 & 93.8 & 21.36 & 22.8 & 13 \\
\hline \multirow[t]{2}{*}{ Body, width } & 17 & 24 & 20.1 & 2.05 & 10.2 & 20 \\
\hline & 20 & 47 & 28.8 & 8.62 & 29.9 & 13 \\
\hline \multirow[t]{2}{*}{ Right somatic kineties, number } & 5 & 7 & 6.2 & 0.52 & 8.4 & 20 \\
\hline & 9 & 11 & 9.9 & 0.64 & 6.5 & 13 \\
\hline \multirow[t]{2}{*}{ Left somatic kineties, number } & 4 & 5 & 5.0 & 0.22 & 4.4 & 20 \\
\hline & 5 & 6 & 5.2 & 0.40 & 7.7 & 11 \\
\hline \multirow[t]{2}{*}{ Cilia in midbody of right side in $10 \mu \mathrm{m}$, number } & 5 & 10 & 7.2 & 1.18 & 16.4 & 19 \\
\hline & 5 & 10 & 6.5 & 1.58 & 24.3 & 10 \\
\hline \multirow[t]{2}{*}{ Dorsal brush dikinetids, number } & 10 & 25 & 14.8 & 3.86 & 26.1 & 18 \\
\hline & 14 & 19 & 16.1 & 1.95 & 12.1 & 7 \\
\hline \multirow[t]{2}{*}{ Macronuclear nodules, number } & 2 & 3 & 2.1 & 0.22 & 10.5 & 20 \\
\hline & 2 & 2 & 2.0 & 0 & 0.0 & 13 \\
\hline \multirow[t]{2}{*}{ Anterior body end to macronucleus, distance } & 20 & 50 & 33.6 & 10.54 & 31.4 & 18 \\
\hline & 29 & 55 & 42.0 & 8.33 & 19.8 & 10 \\
\hline \multirow[t]{2}{*}{ Macronuclear nodules, length } & 18 & 28 & 21.9 & 2.22 & 10.1 & 20 \\
\hline & 15 & 28 & 20.8 & 4.28 & 20.6 & 13 \\
\hline \multirow[t]{2}{*}{ Macronuclear nodules, width } & 9 & 14 & 11.3 & 1.66 & 14.7 & 20 \\
\hline & 13 & 20 & 15.8 & 2.05 & 13.0 & 13 \\
\hline \multirow[t]{2}{*}{ Micronuclei, number } & - & - & - & - & - & - \\
\hline & 1 & 1 & 1.0 & 0 & 0.0 & 5 \\
\hline \multirow[t]{2}{*}{ Micronucleus, diameter } & - & - & - & - & - & - \\
\hline & 2 & 5 & 3.8 & 1.30 & 34.2 & 5 \\
\hline \multirow[t]{2}{*}{ Extrusomes, length } & 6 & 10 & 7.7 & 1.03 & 13.4 & 20 \\
\hline & 4 & 6 & 4.9 & 0.64 & 13.1 & 8 \\
\hline
\end{tabular}

Measurements in $\mu \mathrm{m}$.

$\mathrm{CV}=$ coefficient of variation in \%; Max = maximum; Mean = arithmetic mean; Min = minimum; $n=$ number of specimens measured; $\mathrm{SD}=\mathrm{stan}-$ dard deviation.

jModeltest 2.1.6 (Darriba et al. 2012). Two sets of four Markov chain Monte Carlo (MCMC) were run for $1,000,000$ generations and were sampled every 100th generation. The first $25 \%$ of sampled trees were discarded as burn-in prior to tree reconstruction.

\section{Test of phylogenetic scenarios}

To test the monophyly of Protolitonotidae and of Protolitonotus, two constrained $\mathrm{ML}$ trees were generated with the same toolkit as the unconstrained $\mathrm{ML}$ trees on the CIPRES Portal. Internal relationships within the constrained group and among the remaining taxa were unspecified. The site-wise likelihoods for the resulting constrained topologies and the nonconstrained $\mathrm{ML}$ topology were calculated, using PAUP* (Swofford 2002), and were then subjected to the AU test (Shimodaira 2002) as implemented in CONSEL (Shimodaira and Hasegawa 2001).

\section{RESULTS}

\section{Apolitonotus Iynni gen. et sp. nov}

Morphological description

Cell size about $100-180 \times 15-25 \mu \mathrm{m}$ in vivo when fully extended. Body elongate lanceolate in lateral views, highly contractile, with a distinct tail and a conspicuous neck which occupies about $40 \%$ of body length (Fig. 1A, E-G, 2A-E). Right side flat, with several longitudinal furrows containing ciliary rows; left side somewhat vaulted with three prominent longitudinal grooves (Fig. 2E). Cilia on right side, $7 \mu \mathrm{m}$ long and densely arranged; whereas somatic cilia on left side, only ca. $2 \mu \mathrm{m}$ long, as long as dorsal bristles, and sparsely distributed. Tiny cortical granules densely distributed beneath cell surface (Fig. 1C, 2I).

Cytoplasm colorless or slightly grayish, usually containing several greasily shining globules (ca. $1 \mu \mathrm{m}$ across). Extrusomes clavate, ca. $10 \mu \mathrm{m}$ long, scattered in main body but apparently absent along oral slit (Fig. 1B, D, 2F$\mathrm{H})$. Single subterminal contractile vacuole, ca. $10 \mu \mathrm{m}$ in diameter (Fig. 1F, 2D, E). Two macronuclear nodules (rarely three), centrally located, about $10 \times 5 \mu \mathrm{m}$ in size in vivo (Fig. 1B, 2G, H, J). Locomotion by slowly gliding on substrate, preferably on right side.

Somatic ciliature comprises 5-7 right kineties and 4 or 5 left kineties (Table 1). Rightmost kinety terminates subapically; second rightmost kinety bipolar; other right kineties anteriorly successively shortened along second rightmost kinety and forming a semi-suture in neck portion of body (Fig. 1I, 2J, L). Dorsal brush kinety comprises 10-25 


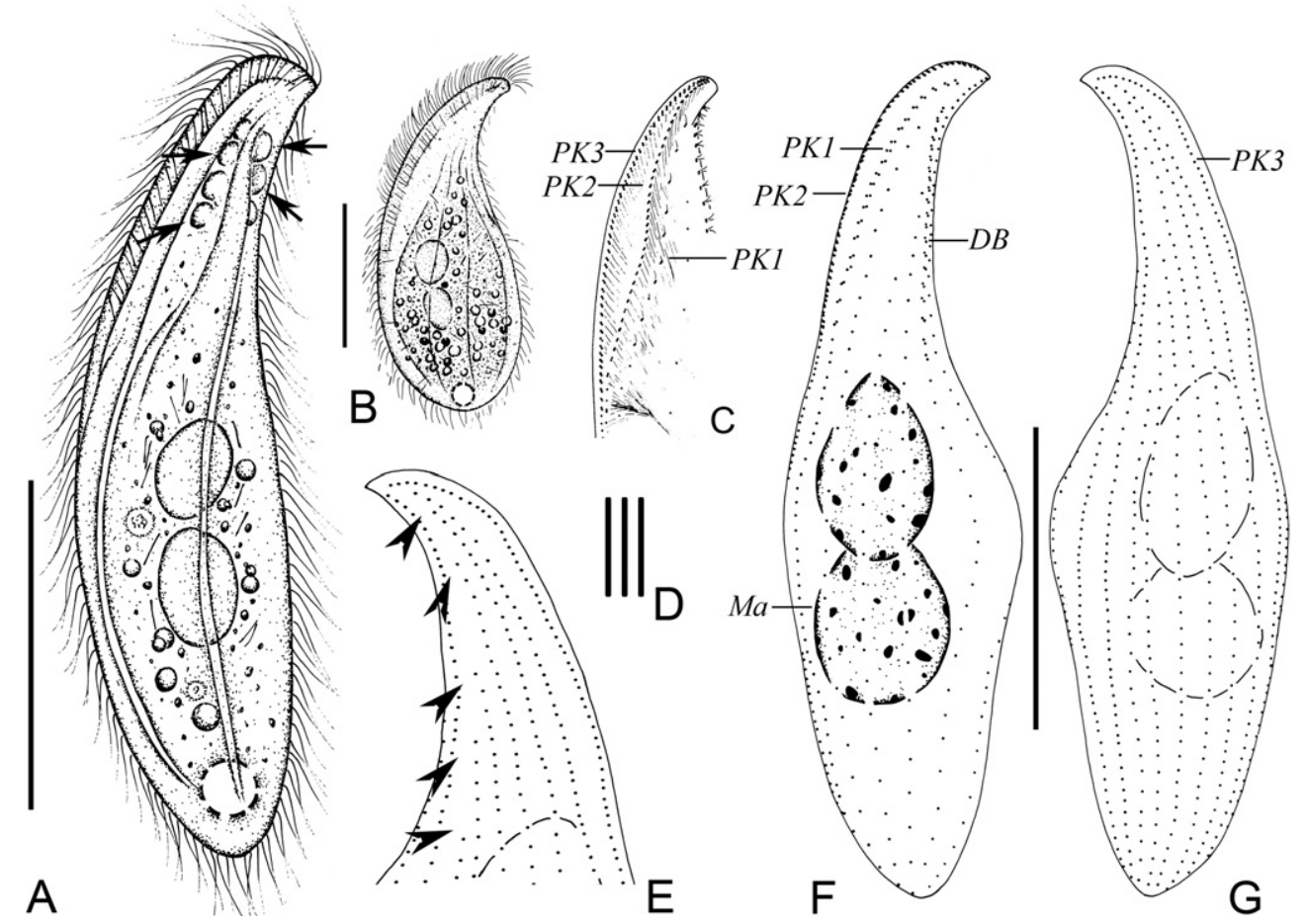

Figure 3 Protolitonotus clampi sp. nov. (A, D-G) and P. antarcticus comb. nov. (B, C) from life (A, B) and after protargol staining (C-G). (A) Left view of a typical individual, arrows refer to the protuberances. (B) Left view, from Song and Wilbert (2002). (C) Anterior part of left side, from Song and Wilbert (2002). (D) Extrusomes, 4-6 $\mu \mathrm{m}$ long. (E) Anterior part of right side, arrowheads mark the semi-suture. (F, G) Ciliary patterns of both left $(F)$ and right $(G)$ sides. $D B=$ dorsal brush; $M a=$ macronuclear nodules; PK1-3 = perioral kineties 1-3. Scale bars: $40 \mu \mathrm{m}$.

ordinary spaced dikinetids in its anterior third and loosely spaced monokinetids in the remaining portion (Fig. $1 \mathrm{H}, 2 \mathrm{~K}$ ).

Three perioral kineties around oral slit (Fig. 1H, I, 2K, L). The perioral kinety 1 on the left of the oral slit, consists of dikinetids in the anterior $2 / 5$ and of monokinetids in the posterior portion. The perioral kineties 2 and 3 on the right of the oral slit; the perioral kinety 2 comprises closely spaced dikinetids in the anterior third and monokinetids in the posterior portion, whereas the perioral kinety 3 is exclusively composed of monokinetids.

\section{SSU rDNA sequence}

The SSU rDNA sequence of Apolitonotus lynni sp. nov. has been deposited in the GenBank database with the accession number, length, and $\mathrm{G}+\mathrm{C}$ content as follows: MK736944, 1,593 bp, and 42.69\%.

\section{Protolitonotus clampi sp. nov}

\section{Morphological description}

Body size about $80-130 \times 15-30 \mu \mathrm{m}$ in vivo when extended. Cell flexible, usually ellipsoidal in outline with broadly rounded posterior end (Fig. 3A, 4A, B). Neck occupying $25 \%$ of body length (Fig. $4 A$, F). Bilaterally compressed about 1:2-1:1.5 (Fig. 4D); right side flat, while left side vaulted with two or three longitudinal grooves (Fig. 4C). About 5-9 protuberances in anterior of left side (Fig. 3A, 4B, E). Right ciliary rows terminate along dorsal margin anteriorly with densely arranged cilia about $6 \mu \mathrm{m}$ long (Fig. 4H). Cilia on left side, ca. $2 \mu \mathrm{m}$ long, as long as dorsal bristles, and sparsely arranged. Two ovoidal macronuclear nodules, centrally located, about $12 \times 8 \mu \mathrm{m}$ in vivo; single micronucleus positioned between the two macronuclear nodules (Fig. 4G, I). One terminal contractile vacuole (Fig. 4B). Extrusomes rod-shaped, ca. 4-6 $\mu \mathrm{m}$ long, densely arranged along oral slit and scattered in cytoplasm (Fig. 3D, 4G, I). Cortex thin; many tiny subcortical granules on both sides of body. Cytoplasm colorless, contains few greasily shining globules.

Somatic ciliature comprises 9-11 right and 5 or 6 left kineties (Fig. 4J, M; Table 1). Two rightmost right kineties bipolar, the other right kineties anteriorly successively shortened, forming a semi-suture near the dorsal margin (Fig. 3E, G, 4H). Dorsal brush kinety comprises 14-19 ordinary spaced dikinetids in its anterior $2 / 5$ and loosely spaced monokinetids in the remaining portion (Fig. 3F, $4 \mathrm{~K})$.

Three perioral kineties (Fig. 3F, G). The perioral kinety 1 on the left of the oral slit, consists of dikinetids in the anterior $2 / 5$ and of monokinetids in the posterior portion. The perioral kineties 2 and 3 on the right of the oral slit; the perioral kinety 2 , similar to the perioral kinety 1 , comprises closely spaced dikinetids in the anterior $2 / 5$ and of monokinetids in the posterior portion, whereas the perioral kinety 3 is exclusively composed of monokinetids. 


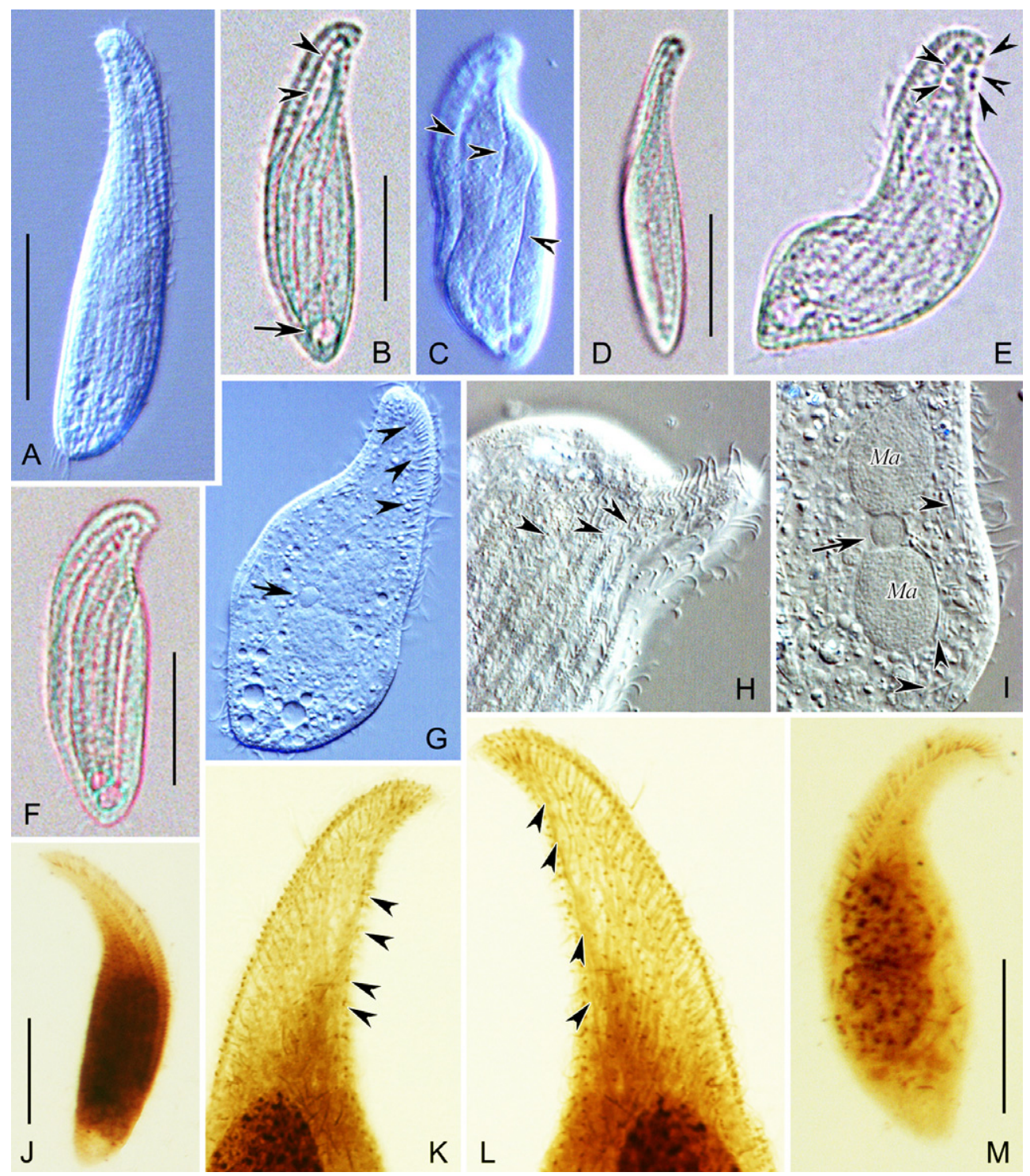

Figure 4 Protolitonotus clampi sp. nov. from life (A-I) and after protargol staining (J-M). (A) Right view. (B, C, E, F) Shape variants, arrowheads in $(B)$ and $(E)$ denote the protuberances in the neck region, and arrowhead in $(C)$ points to the longitudinal grooves; arrow marks the contractile vacuole. (D) Dorsal view. (G) Right view, arrow refers to the micronucleus, arrowheads point to the extrusomes. (H) To show the anterior ends of right somatic kineties (arrowheads). (I) Details of cytoplasm, arrow points to the micronucleus, arrowheads indicate the extrusomes. (J) Right view. (K) Anterior of left side, arrowheads refer to the dorsal brush. (L) Anterior of right side, arrowheads mark the semi-suture. (M) Left view. Scale bars: $40 \mu \mathrm{m}$.

\section{SSU rDNA sequence}

The SSU rDNA sequence of $P$. clampi sp. nov. has been deposited in the GenBank database with the accession number, length, and $\mathrm{G}+\mathrm{C}$ content as follows: MK736945, 1,642 bp, and 41.29\%.

\section{SSU rDNA sequences analyses}

The SSU rDNA sequence of $P$. clampi sp. nov. differs from its congeners in 130-147 nucleotides; thus, sequence similarity ranged from $90.6 \%$ to $91.6 \%$. The pairwise sequence similarities between A. lynni gen. et $\mathrm{sp}$. nov. and
Protolitonotus spp. ranged from $90.4 \%$ to $91.9 \%$ (differing by 121-144 bases). The closest related sequence of $A$. lynni in NCBI's nr database is Litonotus gracilis (KP010148), with 97\% sequence similarity (33 bases different).

The $\mathrm{ML}$ and $\mathrm{BI}$ trees had similar topologies, and therefore, only the ML tree is presented (Fig. 6). In the phylogenetic trees, the order Pleurostomatida comprises four families, that is, the Amphileptidae, Kentrophyllidae, Litonotidae, and Protolitonotidae. The former two families are monophyletic and comprise only one genus each. The new species $P$. clampi does not group with its congeners, but is sister to an undetermined sequence with full support. 

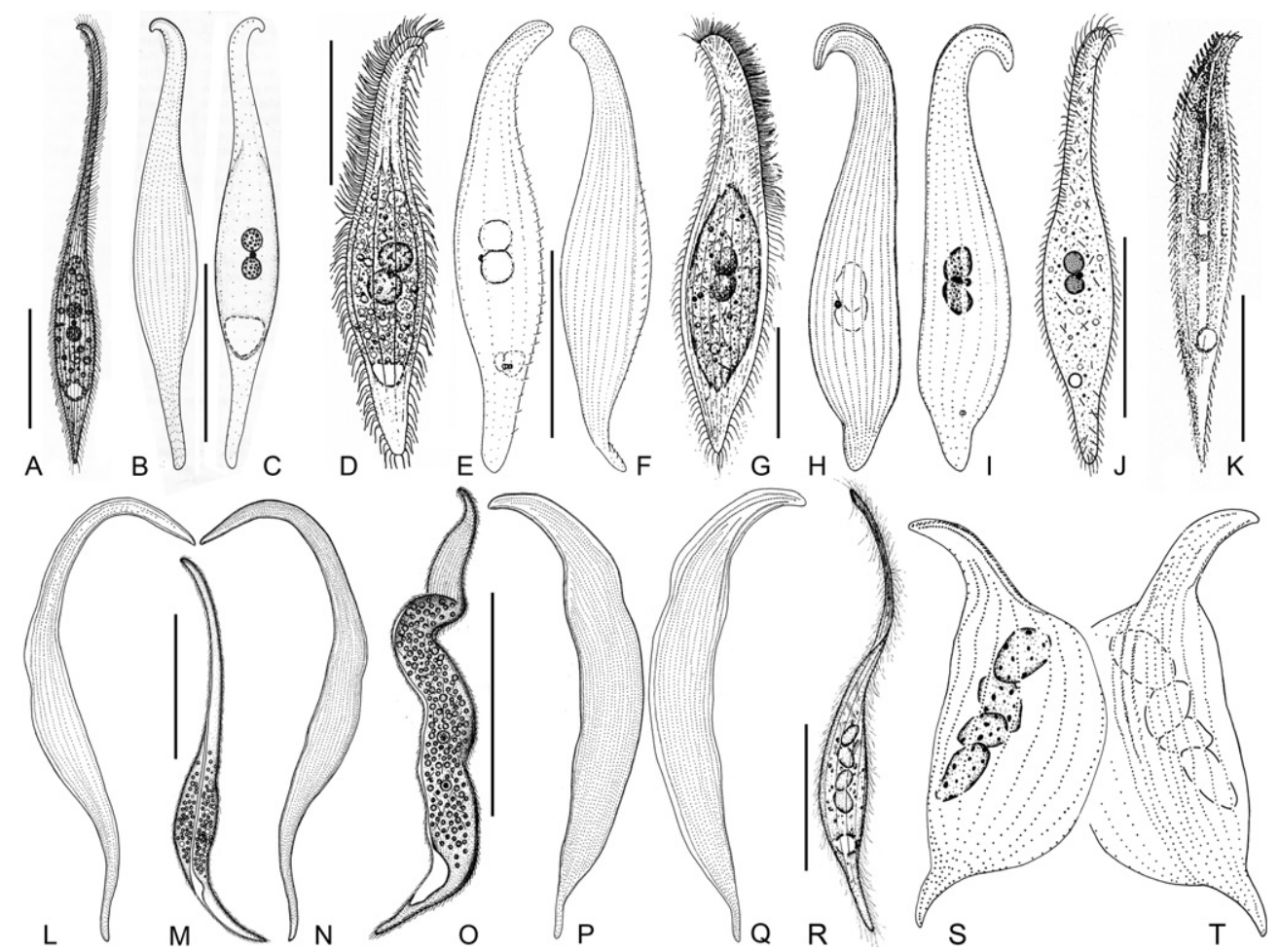

Figure 5 Morphology of related species of Apolitonotus lynni gen. et sp. nov. and Protolitonotus clampi sp. nov. (A-C) Litonotus cygnus, from Foissner (1984). (D-F) Litonotus anguilla, from Song and Wilbert (1989). (G-I) L. paracygus, from Song (1994). (J) L. dusarti, from Dragesco (1960). (K) L. niger, from Vuxanovici (1960). (L-N) P. longus, from Wu et al. (2017). (O-Q) P. magnus from Wu et al. (2017). (R-T) L. gracilis from Pan et al. (2015). Scale bars: $50 \mu \mathrm{m}$ (A-C, G, J, K), $100 \mu \mathrm{m}(\mathrm{D}-\mathrm{F}, \mathrm{R}), 400 \mu \mathrm{m}$ (M, O).

This cluster is again sister to the family Kentrophyllidae (ML/BI, 88/1.00). The sequence from A. lynni clusters with two populations of Litonotus gracilis with full support. This clade is the adelphotaxon to the Kentrophyllidae-P. clampi clade with moderate to high support (ML/BI, 70/0.98), rather than grouping with protolitonotids or litonotids. As a consequence, the two other families of Pleurostomatida, viz., the Litonotidae and Protolitonotidae, are nonmonophyletic in the present analyses.

\section{DISCUSSION}

\section{Apolitonotus is a new genus in the family Protolitonotidae}

The presence of the anterior semi-suture is the unique diagnostic characteristic of Protolitonotidae. Regarding this feature, Apolitonotus resembles Protolitonotus. However, it differs from the latter and the other pleurostomatid genera, except for Apoamphileptus Lin and Song 2004 and Kentrophyllum, in the absence of oral extrusomes, which are a main feature of most free-living litostomateans (Foissner 1984; Lin et al. 2009; Wu et al. 2017). The absence of oral extrusomes is a homoplasious feature and is used to characterize several litostomatean genera, viz., Coriplites, Apocoriplites, and Apotrachelius (Oertel et al. 2008; Vd'ačný and Foissner 2012). Thus, this feature is sufficient for separating A. lynni sp. nov. from Protolitonotus spp. on genus level. Apoamphileptus and Kentrophyllum also lack oral extrusomes; yet, the two genera can be clearly separated from the new genus in having a suture (vs. semi-suture) on the anterior right side (Lin and Song 2004; Lin et al. 2005; Wu et al. 2015a).

\section{Comparison Apolitonotus lynni sp. nov. with similar species}

Litonotus anguilla Kahl, 1931 (Fig. 5D-F), L. cygnus Müller, 1776 (Fig. 5A-C), L. paracygnus Song, 1994 (Fig. 5G-I), L. dusarti Dragesco, 1960 (Fig. 5J), and L. niger Vuxanovici, 1960 (Fig. 5K) are similar to A. Iynni concerning the body shape. Apolitonotus lynni can be clearly distinguished by the lack of oral extrusomes and the semi-suture on the right side. In addition, A. lynni is smaller than L. cygnus in vivo $(100-180 \mu \mathrm{m}$ vs. $200-$ $300 \mu \mathrm{m})$ (Foissner et al. 1995) and has fewer right kineties (5-7) than L. anguilla (10-12), L. paracygnus (12 or 13) and L. dusarti (12) (Dragesco 1960; Song 1994; Song and Wilbert 1989; Vuxanovici 1960).

\section{Comments on Protolitonotus clampi sp. nov}

Protolitonotus is identified by the presence of a semisuture near the right dorsal margin. In its original diagnosis, the presence of extrusomes along the entire ventral 
margin is emphasized (Wu et al. 2017). In some pleurostomatid genera, for example, Litonotus and Loxophyllum, however, the arrangement of extrusomes shows an intrageneric variability, that is, they might insert along the entire ventral margin or only along the oral slit (Foissner et al. 1995; Lin et al. 2009). Therefore, we assign the current form to the genus Protolitonotus, although its extrusomes are restricted to the oral slit. Currently, the genus Protolitonotus comprises two species, namely $P$. magnus Wu et al., 2017 (Fig. 50-Q) and P. longus Wu et al., 2017 (Fig. 5L-N). The new species, P. clampi, can clearly be distinguished from them by its smaller size in vivo (80$130 \times 15-30 \mu \mathrm{m}$ vs. $400-1,350 \times 40-85 \mu \mathrm{m}$ in $P$. magnus and 800-1,400 $\times$ 45-85 $\mu \mathrm{m}$ in $P$. longus), fewer kineties (9-11 right and 5 or 6 left kineties vs. 16-22 right kineties and 12-16 left kineties in P. magnus and 11-14 right kineties and 7-9 left kineties in P. longus), and the number of macronuclear nodules (two vs. hundreds in both $P$. magnus and P. longus) (Wu et al. 2017).

Regarding the general morphology and the ciliary pattern, Protolitonotus clampi resembles Litonotus antarcticus Song and Wilbert, 2002 (Fig. 3B). However, the former differs from the latter by the structures of the
Table 2. Approximately unbiased (AU) test results

\begin{tabular}{ll}
\hline Topology constraints & AU value \\
\hline Monophyly of Protolitonotidae & $5.00 \mathrm{E}-68$ \\
Monophyly of Protolitonotus & 0.004 \\
\hline$P<0.05$ refut
\end{tabular}

$P<0.05$ refutes monophyly; $P>0.05$ does not refute the possibility of monophyly.

perioral kinety 3 (invariably composed of monokinetids vs. of dikinetids in anterior half and monokinetids in posterior half) and the perioral kinety 2 (extending along the entire body length vs. terminating near midbody) (Song and Wilbert 2002). The oral ciliary pattern is regarded as a key characteristic for species identification in Haptoria ( $V d$ 'ačný et al. 2012, 2014); accordingly, the observed differences justify a separation from $L$. antarcticus. Since $L$. antarcticus has the same semi-suture on the right side as Protolitonotidae, and its extrusomes are arranged along the oral slit (Song and Wilbert 2002), the species should be transferred to the genus Protolitonotus, becoming Protolitonotus antarcticus comb. nov.

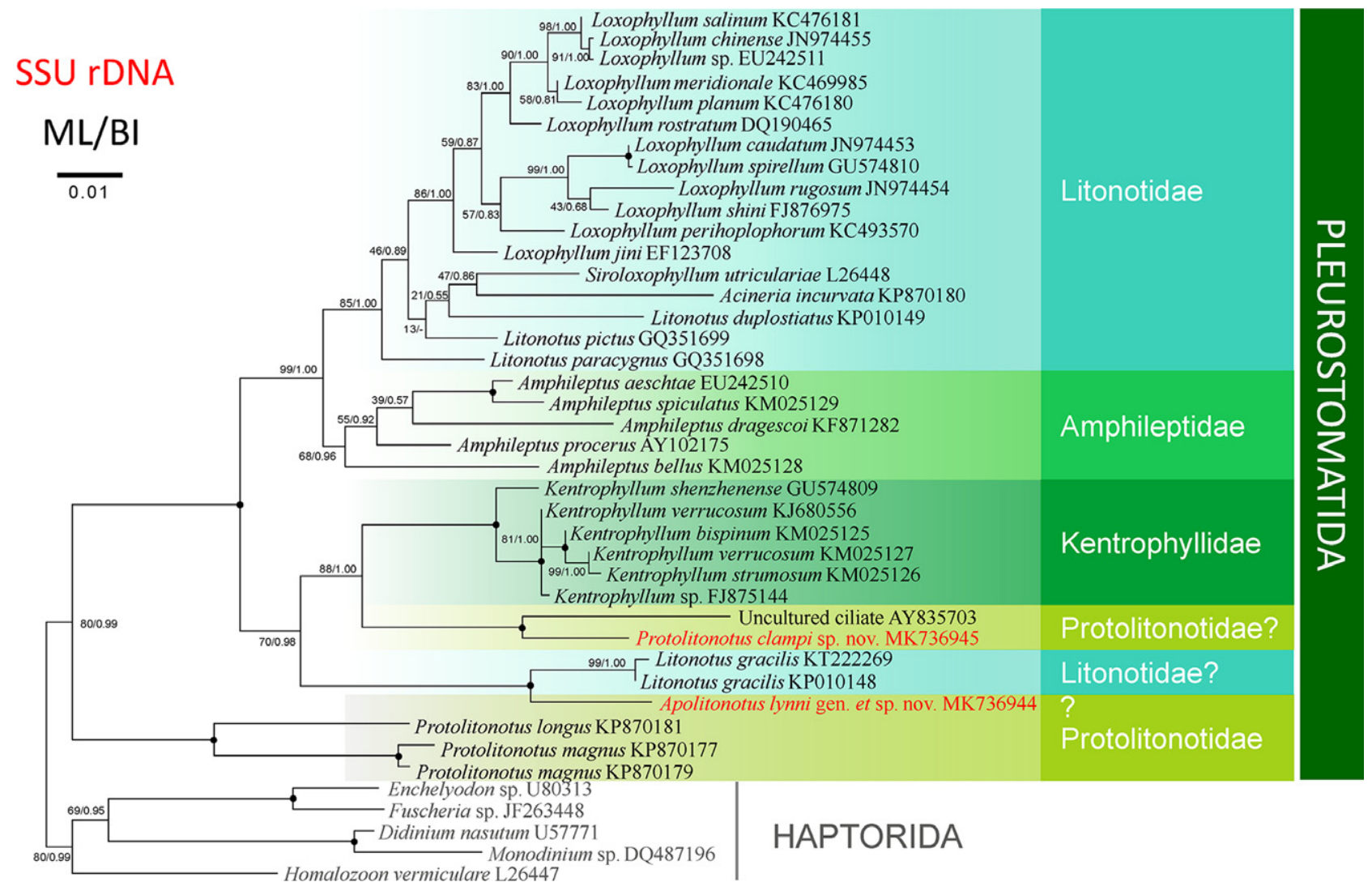

Figure 6 The maximum-likelihood (ML) tree inferred from sequenced SSU rDNA sequences displaying the phylogenetic positions of Apolitonotus lynni gen. et sp. nov. and Protolitonotus clampi sp. nov. (in both red and bold). Numbers at nodes represent the bootstrap values of ML and posterior probabilities of Bayesian analysis (BI). Full support (100\% ML, $1.00 \mathrm{BI})$ in both analyses is marked with solid circle. Clades with a different topology in the BI tree are indicated by a hyphen (-). The scale bar corresponds to one substitution per 100 nucleotides. 


\section{Phylogenetic analysis}

For a long time, the order Pleurostomatida contained only two families, the Litonotidae and Amphileptidae (Lin and Song 2004; Lin et al. 2007, 2008a,b; Lynn 2008; Lynn and Small 2002). Recently, another two families, the Kentrophyllidae and Protolitonotidae, have been established (Wu et al. 2015a, 2017). The present analysis based on SSU rDNA sequences suggests that $P$. clampi sp. nov. and A. Iynni gen. et sp. nov. have no phylogenetic affiliations with any extant families, which challenges the morphological conclusion.

Protolitonotus clampi clusters with the Kentrophyllidae clade rather than with the other Protolitonotus species. Moreover, the hypothesis about the monophyly of the genus Protolitonotus is rejected by the AU test $(P<0.05$; Table 2). Instead, these tests robustly support a separation of $P$. clampi from the congeners. However, P. clampi can be morphologically clearly distinguished from the Kentrophyllidae by the ciliary pattern on the right side (semisuture vs. two sutures) and the shape of perioral kinety 2 (bipolar vs. encircling margin of cell) (Wu et al. 2015a). These data suggest that $P$. clampi might represent a distinct lineage within the order Pleurostomatida. Another possible interpretation is that the character semi-suture represents a homoplasy that does not reflect phylogenetic relationships. Otherwise, given that $P$. clampi is the only morphologically studied species within its clade, and the two known Protolitonotus species, P. clampi and P. Iynni, shared so many characters (e.g., the number of macronuclear nodules, the shape and the distribution pattern of extrusomes), it is currently impossible to provide morphological characters for distinguishing $P$. clampi from other protolitonotids at generic or even higher level (details in the "Remarks" section above). Therefore, we tentatively assign $P$. clampi sp. nov. to Protolitonotus pending the availability of more data, for example, concerning the ultrastructure and more congeners.

Apolitonotus lynni does not cluster with Protolitonotus spp., which supports the establishment of the new genus. According to Wu et al. (2017), the presence of the anterior semi-suture is the unique diagnostic feature of the Protolitonotidae. Therefore, it is reasonable to assign Apolitonotus to the Protolitonotidae based on this morphological characteristic. However, this affiliation is still challenged by the SSU phylogeny. Apolitonotus lynni does not group to protolitonotids, and the AU test rejects the monophyly of Protolitonotidae $(P<0.05$; Table 2$)$. Instead, A. Iynni groups with Litonotus gracilis and shows affiliation to the Kentrophyllidae and $P$. clampi. This phylogenetic position of $A$. lynni is surprising as the species $A$. lynni can morphologically be distinguished from L. gracilis (Fig. 5R$\mathrm{T}$ ) by the presence of the semi-suture on the right side (vs. absence of semi-suture or suture) and the absence of oral extrusomes (vs. presence), and they do not share any characteristics which can be used to explain their distinct phylogenetic position in pleurostomatids (Pan et al. 2015). The discrepancy between the results of the phylogenetic analysis and the morphological investigation indicates the diagnostic feature of Protolitonotidae, that is, somatic ciliary rows forming a semi-suture, is likely a homoplasious character which evolved at least twice independently, viz., in A. Iynni and in P. clampi. Furthermore, our phylogenetic result partly supports the previous findings suggesting that the family Protolitonotidae with the cluster formed by $P$. magus and $P$. longus might be the basal lineage within the order Pleurostomatida, with the cluster of P. magus $+P$. longus basally positioned (Wu et al. 2017). Additionally, the absence of oral extrusomes is not only reported in Apolitonotus and Kentrophyllum, but also found in haptorids, for example, the Coriplitidae and some arcuospathidiids. Vd'ačný et al. (2011) pointed out that the loss of oral extrusomes is a homoplasy in the class Litostomatea, which is supported by our findings.

\section{TAXONOMIC SUMMARY}

Class Litostomatea Small and Lynn, 1981

Subclass Haptoria Corliss, 1974

Order Pleurostomatida Schewiakoff, 1896

Family Protolitonotidae Wu et al. 2017

Apolitonotus gen. nov.

Diagnosis. Protolitonotids with one to several bipolar kineties in rightmost region of cell; oral extrusomes secondarily lacking.

Type species. Apolitonotus lynni sp. nov.

Etymology. Composite of the Greek prefix "apo" (derive from) and the generic name Litonotus referring to the Litonotus-like general organization. Masculine gender.

ZooBank registration number. urn:Isid:zoobank.org: act:45302A63-07C7-4704-A543-E8BA0540B675.

Remarks. Since Apolitonotus possesses a semi-suture, the unique diagnostic feature of the Protolitonotidae, we tentatively assign it to this family, although Apolitonotus does not cluster with other protolitonotids in the phylogenetic tree.

Apolitonotus lynni sp. nov.

Diagnosis. Cell size about 100-180 × 15-25 $\mu \mathrm{m}$ in vivo, elongate lanceolated with a distinct tail in lateral view; 4 or 5 left kineties, 5-7 right kineties; extrusomes clavate; contractile vacuole subterminal; usually two macronuclear nodules.

Type materials. One protargol slide with the holotype was deposited in Laboratory of Protozoology, Ocean University of China, with the registration number PHB2010040706-1. Another protargol slide with paratypes was deposited in Natural History Museum, UK, with the registration number NHMUK 2019.12.3.1.

Type locality. Mangrove wetland in Techeng Island $\left(21^{\circ} 08^{\prime} 52^{\prime \prime} \mathrm{N}, 110^{\circ} 26^{\prime} 20^{\prime \prime} \mathrm{E}\right), \quad$ Zhanjiang, Guangdong Province, China.

Dedication. We dedicate this species to Prof. Dr. Denis Lynn, an outstanding protistologist, on recognition of his significant contribution on the phylogeny and taxonomy of ciliates.

ZooBank registration number. urn:Isid:zoobank.org: act:13FC5669-5A61-4097-8D68-05A2C799D971. 
Genus Protolitonotus Wu et al., 2017.

Improved diagnosis of Protolitonotus. Based on the information outlined above, an improved diagnosis of the genus Protolitonotus has to be suggested: Protolitonotids with one to several biopolar kineties in rightmost region of cell; oral extrusomes present.

Protolitonotus clampi sp. nov.

Diagnosis. Cell size about $80-130 \times 15-30 \mu \mathrm{m}$ in vivo; elongated lanceolate in lateral view; 5 or 6 left and 9-11 right kineties; 3 perioral kineties; contractile vacuole terminal; extrusomes rod-shaped, arranged along oral slit and scattered in cytoplasm; two macronuclear nodules and single micronucleus.

Type materials. One protargol slide with the holotype was deposited in Laboratory of Protozoology, Ocean University of China, with the registration number PHB09102902-1. Another protargol slide with paratypes was deposited in Natural History Museum, UK, with the registration number NHMUK 2019.12.3.2.

Type locality. Coast water of Qingdao Olympic Sailing Centre $\left(36^{\circ} 03^{\prime} 26.7^{\prime \prime} \mathrm{N}, 120^{\circ} 23^{\prime} 42.8^{\prime \prime} \mathrm{E}\right)$ in Qingdao, China.

Dedication. We dedicate this species to our respected colleague and good friend, Prof. Dr. John Clamp, in recognition of his significant contribution on the phylogeny and taxonomy of ciliates, especially Peritrichia.

ZooBank registration number. urn:Isid:zoobank.org: act:71EF5B8E-C4DE-465D-BCFA-E690772A1EA9.

ZooBank LSID of the paper. urn:Isid:zoobank.org: pub:8B281375-8D0F-4665-8685-2F846CC8F5AB.

\section{ACKNOWLEDGMENTS}

We are very grateful to the Associate Editor and the two reviewers for their valuable suggestions. This work was supported by National Nature Science Foundation of China (No. 31772477 to JJ, 31672251 to QZ, 31201703 to HP), Science and Technology Commission of Shanghai Municipality (No. 19050501900), Youth Innovation Promotion Association, Chinese Academy of Sciences (No. 2019216) and Shanghai Collaborative Innovation for Aquatic Animal Genetics and Breeding.

\section{LITERATURE CITED}

Cairns, J. \& Yongue, W. H. 1968. The distribution of freshwater protozoa on a relatively homogenous substrate. Hydrobiologia, 31:65-72.

Castresana, J. 2000. Selection of conserved blocks from multiple alignments for their use in phylogenetic analysis. Mol. Biol. Evol., 17:540-552.

Chen, L., Wu, W., El-Serehy, H. A., Hu, X. \& Clamp, J. C. 2018. Morphology, morphogenesis, and phylogeny of an Anteholosticha intermedia (Ciliophora, Urostylida) population from the United States. Eur. J. Protistol., 65:1-15.

Darriba, D., Taboada, G. L., Doallo, R. \& Posada, D. 2012. jModelTest 2: more models, new heuristics and parallel computing. Nat. Methods, 9:772.

Dopheide, A., Lear, G., Stott, R. \& Lewis, G. 2009. Relative diversity and community structure of ciliates in stream biofilms according to molecular and microscopy methods. Appl. Environ. Microbiol., 75:5261-5272.

Dragesco, J. 1960. Ciliés mésopsammiques littoraux, systématique, morphologie, écologie. Trav. Stat. Biol. Roscoff, 12:1-356.

Edgar, R. C. 2004. MUSCLE: multiple sequence alignment with high accuracy and high throughput. Nucleic Acids Res., 32:1792-1797.

Foissner, W. 1984. Taxonomie und Ökologie einiger Ciliaten (Protozoa, Ciliophora) des Saprobiensystems. I: genera Litonotus, Amphileptus, Opisthodon. Hydrobiologia, 119:193-208.

Foissner, W., Berger, H., Blatterer, H. \& Kohmann, F. 1995. Taxonomische und ökologische Revision der Ciliaten des Saprobiensystems - Band IV: Gymnostomatea, Loxodes, Suctoria. Infromat Bayer Land. Wasserwirt, 1/95:1-540.

Gao, S., Song, W. B., Ma, H., Clamp, J. C., Yi, Z., Al-Rasheid, K. A., Chen, Z. \& Lin, X. 2008. Phylogeny of six genera of the subclass Haptoria (Ciliophora, Litostomatea) inferred from sequences of the gene coding for small subunit ribosomal RNA. J. Eukaryot. Microbiol., 55:562-566.

Gao, F., Warren, A., Zhang, Q., Gong, J., Miao, M., Sun, P., Xu, D., Huang, J., Yi, Z. \& Song, W. B. 2016. The all-data-based evolutionary hypothesis of ciliated protists with a revised classification of the phylum Ciliophora (Eukaryota, Alveolata). Sci. Rep., 6:24874.

Hu, X. Z., Lin, X. F. \& Song, W. B. 2019. Ciliates atlas: species found in the South China Sea, 1st ed. Science Press, Beijing.

Huang, J. B., Zhang, T., Zhang, Q., Li, Y., Warren, A., Pan, H. \& Yan, Y. 2018. Further insights into the highly derived haptorids (Ciliophora, Litostomatea): phylogeny based on multigene data. Zool. Scr., 47:231-242.

Lin, X. F., Al-Rasheid, K. A., Al-Quraishy, S. A., Al-Farraj, S. A. \& Song, W. B. 2008a. Identification of three highly confused marine Loxophyllum (Ciliophora: Pleurostomatida) with a key to seven congeners from the China Sea. J. Eukaryot. Microbiol., 55:331-342.

Lin, X. F., Li, J., Gong, J., Warren, A. \& Song, W. B. 2008b. Taxonomic studies on three marine pleurostomatid ciliates, Litonotus bergeri nov. spec., L. blattereri nov. spec. and L. petzi nov. spec. (Ciliophora, Pleurostomatida) from North China Sea. Eur. J. Protistol., 44:91-102.

Lin, X. F. \& Song, W. B. 2004. Establishment of a new amphileptid genus, Apoamphileptus nov. gen. (Ciliophora, Litostomatea, Pleurostomatida), with description of a new marine species, Apoamphileptus robertsi nov. spec. from Qingdao. J. Eukaryot. Microbiol., 51:618-625.

Lin, X. F., Song, W. B. \& Li, J. 2007. Amphileptus aeschtae nov. spec. and Amphileptus eigneri nov. spec. (Ciliophora, Pleurostomatida), two new marine pleurostomatid ciliates from China. Eur. J. Protistol., 43:77-86.

Lin, X. F., Song, W. B. \& Warren, A. 2005. Taxonomic studies on three marine pleurostomatid ciliates: Kentrophyllum verrucosum (Stokes, 1893) Petz, Song et Wilbert, 1995, Epiphyllum soliforme (Fauré-frémiet, 1908) gen. n., comb. n. and Amphileptus sikorai sp. n., with the establishment of a new genus Epiphyllum (Ciliophora: Pleurostomatida). Acta Protozool., 44:129-145.

Lin, X. F., Warren, A. \& Song, W. B. 2009. Pleurostomatids. In: Song, W. B., Warren, A. \& Hu, X. Z. (ed.), Free-living ciliates in the Bohai and Yellow Seas, China. Science Press, Beijing. p. 93-134.

Liu, W., Jiang, J., Xu, Y., Pan, X., Qu, Z., Luo, X., El-Serehy, H. A., Warren, A., Ma, H. \& Pan, H. 2017. Diversity of free-living marine ciliates (Alveolata, Ciliophora): faunal studies in coastal waters of China during the years 2011-2016. Eur. J. Protistol., 61:424-438.

Lynn, D. 2008. The ciliated protozoa, characterization, classification, and guide to the literature. Springer, Dordrecht. 
Lynn, D. \& Small, E. B. 2002. Phylum Ciliophora Doflein, 1901. In: Lee, J. J., Leedale, G. F. \& Bradbury, P. (ed.), An illustrated guide to the protozoa. Allen Press Inc., Lawrence, KS, p. 371-656.

Medlin, L., Elwood, H. J., Stickel, S. \& Sogin, M. L. 1988. The characterization of enzymatically amplified eukaryotic 16S-like rRNA-coding regions. Gene, 71:491-499.

Miller, M. A., Pfeiffer, W. \& Schwartz, T. 2010. Creating the CIPRES Science Gateway for inference of large phylogenetic trees. In: Proceedings of the Gateway Computing Environments Workshop (GCE), New Orleans, LA. p. 1-8.

Oertel, A., Wolf, K., Al-Rasheid, K. A. S. \& Foissner, W. 2008. Revision of the genus Coriplites Foissner, 1988 (Ciliophora: Haptorida), with description of Apocoriplites nov. gen. and three new species. Acta Protozool., 47:231-246.

Pan, H., Gao, F., Li, J. Q., Lin, X. F., Al-Farraj, S. A. \& Al-Rasheid, K. A. S. 2010. Morphology and phylogeny of two new pleurostomatid Ciliates, Epiphyllum shenzhenense n. sp. and Loxophyllum spirellum n. sp. (Protozoa, Ciliophora) from a mangrove wetland, South China. J. Eukaryot. Microbiol., 57:421-428.

Pan, H., Gao, F., Lin, X. F., Warren, A. \& Song, W. B. 2013. Three new Loxophyllum species (Ciliophora: Pleurostomatida) from China with a brief review of the marine and brackish Loxophyllum Species. J. Eukaryot. Microbiol., 60:44-56.

Pan, H., Li, L., Lin, X., Li, J., Al-Farraj, S. A. \& Al-Rasheid, K. A. S. 2014. Morphology of three species of Amphileptus (Protozoa, Ciliophora, Pleurostomatida) from the South China Sea, with note on phylogeny of $A$. dragescoi sp. n. J. Eukaryot. Microbiol., 61:644-654.

Pan, H., Li, L., Wu, L., Miao, M., Al-Rasheid, K. A. S. \& Song, W. B. 2015. Morphology of three Litonotus species (Ciliophora: Pleurostomatida) from China seas, with brief notes on their SSU rDNA-based phylogeny. Eur. J. Protistol., 51:494-506.

Ronquist, F. \& Huelsenbeck, J. P. 2003. MRBAYES 3: Bayesian phylogenetic inference under mixed models. Bioinformatics, 19:1572-1574.

Shimeta, J., Cutajar, J., Watson, M. G. \& Vlamis, T. 2012. Influences of biofilm-associated ciliates on the settlement of marine invertebrate larvae. Mar. Ecol. Prog. Ser., 449:1-12.

Shimodaira, H. 2002. An approximately unbiased test of phylogenetic tree selection. Syst. Biol., 51:492-508.

Shimodaira, H. \& Hasegawa, M. 2001. CONSEL: for assessing the confidence of phylogenetic tree selection. Bioinformatics, 17:1246-1247.

Song, W. B. 1994. Morphology and infraciliature of a new marine ciliate, Litonotus paracygnus nov. sp. (Ciliophora, Pleurostomatida). Acta Zool. Sin., 40:131-136.

Song, W. B., Warren, A. \& Hu, X. 2009. Free-living ciliates in the Bohai and Yellow Sea. Science Press, Beijing.

Song, W. B. \& Wilbert, N. 1989. Taxonomische Untersuchungen an Aufwuchsciliaten (Protozoa, Ciliophora) im Poppelsdorfer Weiher, Bonn. Lauterbornia, 3:2-221.

Song, W. B. \& Wilbert, N. 2002. Faunistic studies on marine ciliates from the Antarctic benthic area, including descriptions of one epizoic form, 6 new species and 2 new genera (Protozoa: Ciliophora). Acta Protozool., 41:23-61.

Stamatakis, A. 2014. RAxML version 8: a tool for phylogenetic analysis and post-analysis of large phylogenies. Bioinformatics, 30:1312-1313.

Swofford, D. L. 2002. PAUP*. Phylogenetic analysis using parsimony (*and other methods). Ver. 4.

Vd'ačný, P., Bourland, W. A., Orsi, W., Epstein, S. S. \& Foissner, W. 2011. Phylogeny and classification of the Litostomatea (Protista, Ciliophora), with emphasis on free-living taxa and the $18 \mathrm{~S}$ rRNA gene. Mol. Phylogenet. Evol., 59:510-522.
Vd'ačný, P., Bourland, W. A., Orsi, W., Epstein, S. S. \& Foissner, W. 2012. Genealogical analyses of multiple loci of litostomatean ciliates (Protista, Ciliophora, Litostomatea). Mol. Phylogen. Evol., 65:397-411.

Vd'ačný, P., Breiner, H. W., Yashchenko, V., Dunthorn, M., Stoeck, T. \& Foissner, W. 2014. The chaos prevails: molecular phylogeny of the Haptoria (Ciliophora, Litostomatea). Protist, 165:93-111.

Vd'ačný, P. \& Foissner, W. 2012. Monograph of the dileptids (Protista, Ciliophora, Rhynchostomatia). Denisia, 31:1-529.

Vd'ačný, P., Rajter, L., Shazib, S. U. A., Jang, S. W., Kim, J. H. \& Shin, M. K. 2015. Reconstruction of evolutionary history of pleurostomatid ciliates (Ciliophora, Litostomatea, Haptoria): interplay of morphology and molecules. Acta Protozool., 54:9-29.

Vuxanovici, A. 1960. Contributii la studiul grupei subgenurilor Litonotus-Hemiophrys (Ciliata). Stud. Cercet. Biol. (Anim.), 12:125-139.

Wang, Y. R., Wang, C. D., Jiang, Y. H., Katz, L. A., Gao, F. \& Yan, Y. 2019. Further analyses of variation of ribosome DNA copy number and polymorphism in ciliates provide insights relevant to studies of both molecular ecology and phylogeny. Sci. China Life Sci., 62:203-214.

Warren, A., Patterson, D. J., Dunthorn, M., Clamp, J. C., AchillesDay, U. E. M., Aescht, E., Al-Farraj, S. A., Al-Quraishy, S., Al-Rasheid, K., Carr, M., Day, J. G., Dellinger, M., El-Serehy, H. A., Fan, Y., Gao, F., Gao, S., Gong, J., Gupta, R., Hu, X., Kamra, K., Langlois, G., Lin, X., Lipscomb, D., Lobban, C. S., Luporini, P., Lynn, D. H., Ma, H., Macek, M., Mackenzie-Dodds, J., Makhija, S., Mansergh, R. I., Martín-Cereceda, M., McMiller, N., Montagnes, D. J. S., Nikolaeva, S., Ong'ondo, G. O., Pérez-Uz, B., Purushothaman, J., Quintela-Alonso, P., Rotterová, J., Santoferrara, L., Shao, C., Shen, Z., Shi, X., Song, W. B., Stoeck, T., La Terza, A., Vallesi, A., Wang, M., Weisse, T., Wiackowski, K., Wu, L., Xu, K., Yi, Z., Zufall, R. \& Agatha, S. 2017. Beyond the "Code": a guide to the description and documentation of biodiversity in ciliated protists (Alveolata, Ciliophora). J. Eukaryot. Microbiol., 64:539-554.

Wilbert, N. 1975. Eine verbesserte Technik der Protargolimprägnation für Ciliaten. Mikrokosmos, 64:171-179.

Wu, L., Chen, R. M., Yi, Z. Z., Li, J. Q., Warren, A. \& Lin, X. 2013. Morphology and phylogeny of three new Loxophyllum species (Ciliophora, Pleurostomatida) from mangrove wetlands of Southern China. J. Eukaryot. Microbiol., 60:267-281.

Wu, L., Chen, R. M., Yi, Z. Z., Li, J. Q., Warren, A. \& Lin, X. 2014. The morphology of three Loxophyllum species (Ciliophora, Pleurostomatida) from southern China, L. lembum sp. n., $L$. vesiculosum sp. n. and L. perihoplophorum Buddenbrock, 1920, with notes on the molecular phylogeny of Loxophyllum. J. Eukaryot. Microbiol., 61:115-125.

Wu, L., Clamp, J. C., Yi, Z., Li, J. \& Lin, X. 2015a. Phylogenetic and taxonomic revision of an enigmatic group of haptorian ciliates, with establishment of the Kentrophyllidae fam. n. (Protozoa, Ciliophora, Litostomatea, Pleurostomatida). PLoS ONE, 10:e0123720.

Wu, L., Jiao, X., Shen, Z., Yi, Z., Li, J., Warren, A. \& Lin, X. 2017. New taxa refresh the phylogeny and classification of pleurostomatid ciliates (Ciliophora, Litostomatea). Zool. Scr., 46:245-253.

Wu, L., Yi, Z., Li, J., Warren, A., Xu, H. \& Lin, X. 2015b. Two new brackish ciliates, Amphileptus spiculatus sp. $\mathrm{n}$. and A. bellus sp. $\mathrm{n}$. from mangrove wetlands in southern China, with notes on the molecular phylogeny of the family Amphileptidae (Protozoa, Ciliophora, Pleurostomatida). J. Eukaryot. Microbiol., 62:662-669.

Xu, H. L., Zhang, W., Jiang, Y. \& Yang, E. J. 2014. Use of biofilmdwelling ciliate communities to determine environmental quality status of coastal waters. Sci. Total Environ., 470:511-518.

Zhang, Q., Simpson, A. \& Song, W. B. 2012. Insights into the phylogeny of systematically controversial haptorian ciliates (Ciliophora, Litostomatea) based on multigene analyses. Proc. $R$. Soc. Lond. B Biol. Sci., 279:2625-2635. 